\title{
EFEKTIVITAS PASAL 28 AYAT (1) UU ITE TENTANG PENYEBARAN BERITA BOHONG (HOAX)
}

\author{
Oleh : \\ Firda Laily Mufid \\ Email :firdalaily25@gmail.com \\ Universitas Islam Jember \\ Tioma Roniuli Hariandja \\ Email :Tiomahariandja@uij.ac.id \\ Universitas Islam Jember
}

\begin{abstract}
Abstrak
Kehadiran internet dapat memudahkan manusia dalam memperoleh, mengolah dan menyajikan informasi sehingga manusia sangat lancar dalam menjalankan urusan-urusannya di tingkat nasional maupun internasional, misalnya dalam hal pendidikan, kebudayaan, kekerabatan, teknologi, kesenian, perdagangan, perbankan, dan pemerintahan. Salah satu kejahatan yang dapat dilakukan secara on line adalah penyebaran berita bohong (hoax). Hoax bertujuan membuat opini publik, menggiring opini, membentuk persepsi, juga untuk having fun yang menguji kecerdasan dan kecermatan pengguna internet dan media sosial. . Kasus Hoax terjadi dan begitu pesat penyebarannya dikarenakan faktor masyarakat yang mudah percaya. Sehingga penyebaran informasi mudah tersebar dari mulut ke mulut baik itu tersebar melalui media oline seperti whatsapp dan facebook. Dan salah satu desa yang akan diteliti oleh peneliti adalah Desa Sanenrejo, Kecamatan Tempurejo, Kabupaten Jember
\end{abstract}

Kata Kunci: internet, kejahatan internet, Hoax

\begin{abstract}
The presence of the internet can make it easier for humans to obtain, process and present information so that humans are very smooth in carrying out their affairs at the national and international levels, for example in terms of education, culture, kinship, technology, art, commerce, banking, and government. One of the crimes that can be placed on line is the dissemination of false news (hoaxes). Hoax aims to create public opinion, lead opinion, form perceptions, also to have fun that tests the intelligence and accuracy of internet and social media users. . The Hoax case occurred and the spread was so rapid because of the people who easily believed. So that the dissemination of information easier to spread good word of mouth that spread through the media oline like whatsapp and facebook. And one of the villages that will be studied by the researchers is Desa Sanenrejo, Kecamatan Tempurejo, Jember
\end{abstract}

Keywords: internet, internet crime, hoax

JURNAL RECHTENS, Vol. 8, No. 2, Desember 2019 


\section{PENDAHULUAN}

\subsection{Latar Belakang}

Perkembangan ilmu, pengetahuan, teknologi dan seni mengantarkan manusia memasuki "era digital" melahirkan internet sebagai sebuah jaringan, dan juga sebuah "lambang eksklusivitas". Sebagai sebuah jaringan, internet mampu meng-koneksikan antar subsistem jaringan menjadi satu jaringan super besar yang terhubung (online) seluruh dunia. Bahkan teknologi internet mampu meng-konvergensi-kan data, informasi, audio, visual yang dapat berpengaruh pada kehidupan manusia.

Bersamaan perkembangan teknologi telematika yang semakin canggih sudah semakin merasuk dalam aktivitas kehidupan manusia di tengah hembusan arus globalisasi dunia maka keberadaan masyarakat maya-pun semakin meluas. Bahkan sebagai imitasi dari masyarakat nyata (real community), masyarakat maya telah membangun sistem kemasyarakatan sebagaimana model dalam segi kehidupan masyarakat nyata, seperti : interaksi sosial, stratifikasi sosial, kebudayaan, pranata sosial, kekuasaan dan juga sistem kejahatan.

Kehadiran internet dapat memudahkan manusia dalam memperoleh, mengolah dan menyajikan informasi sehingga manusia sangat lancar dalam menjalankan urusan-urusannya di tingkat nasional maupun internasional, misalnya dalam hal pendidikan, kebudayaan, kekerabatan, teknologi, kesenian, perdagangan, perbankan, dan pemerintahan. Bahkan, saat ini internet sudah dapat membantu manusia dalam sejumlah urusan, termasuk dalam bidang kesehatan, transportasi, dan pengembangan hukum dan politik.

Selain dampak positif tesebut, ada juga dampak negatif yang dapat ditimbulkan dengan adanya internet tersebut. Internet membuat kejahatan yang semula bersifat konvensional seperti pengancaman, pencurian, pencemaran nama baik, pornografi, perjudian, penipuan hingga tindak pidana terorisme kini melalui media internet, beberapa jenis tindak pidana tersebut dapat dilakukan secara on line oleh individu maupun kelompok dengan resiko tertangkap yang sangat kecil dengan akibat kerugian yang lebih besar baik untuk masyarakat maupun negara.

Salah satu kejahatan yang dapat dilakukan secara on line adalah penyebaran berita bohong (hoax). Hoax bertujuan membuat opini publik, menggiring opini, membentuk persepsi, juga untuk having fun yang menguji kecerdasan dan kecermatan pengguna internet dan media sosial. Hoax merupakan ekses negatif kebebasan berbicara dan berpendapat di internet, kata hoax berasal dari Amerika dan awalnya merupakan sebuah judul film yakni "The Hoax". Hoax terkategori sebagai perbuatan 
melawan hukum. Saat ini perbuatan melawan hukum di dunia maya merupakan fenomena yang sangat mengkhawatirkan, mengingat tindakan carding, hacking, penipuan, terorisme, hoax, telah menjadi aktifitas pelaku kejahatan di dunia maya, hal ini masih sangat kontras dengan kurangnya regulasi yang mengatur pemanfaatan tekhnologi informasi dan komunikasi di berbagai sektor dimaksud.

Ancaman pidana bagi penyebar hoaxdiatur dalam UU No. 19 Tahun 2016 Tentang Informasi dan Transaksi Elektronik, antara lain: Pasal 28 Ayat (1) UU ITE berisi "Setiap orang dengan sengaja dan tanpa hak menyebarkan berita bohong dan menyesatkan yang mengakibatkan kerugian konsumen dalam Transaksi Elektronik", Pasal 28 Ayat (2) UU ITE berisi "Setiap orang dengan sengaja dan tanpa hak menyebarkan informasi yang ditujukan untuk menimbulkan rasa kebencian atau permusuhan individu dan/atau kelompok masyarakat tertentu berdasarkan suku, agama, ras, dan antar golongan (SARA). Ketentuan pidana pada UU ITE tercantum rincian ancaman pidana bagi penyebar hoax, Pasal 45 UU ITE berbunyi “setiap orang yang memenuhi unsur yang dimaksud dalam Pasal 28 Ayat (1) dan (2) maka dipidana penjara paling lama enam tahun dan atau denda paling banyak Rp 1 Milyar".
Penyebar berita bohong atau hoax dapat dijerat dengan 2 (dua) Pasal dalam KUHP, yakni Pasal 14 Ayat (1) Barang siapa, dengan menyiarkan berita bohong, dengan sengaja menerbitkan keonaran dikalangan rakyat, dihukum dengan hukuman penjara setinggi-tingginya sepuluh tahun. (2) Barang siapa menyiarkan suatu berita atau mengeluarkan pemberitahuan yang dapat menerbitkan keonaran di kalangan rakyat, sedangkan ia patut dapat menyangka bahwa berita atau pemberitahuan itu adalah bohong, dihukum dengan penjara setinggi-tingginya tiga tahun.

Pasal 15 berisi "Barangsiapa menyiarkan kabar yang tidak pasti atau kabar yang berkelebihan atau yang tidak lengkap, sedangkan ia mengerti setidaktidaknya patut dapat menduga bahwa kabar demikian akan atau sudah dapat menerbitkan keonaran di kalangan rakyat, dihukum dengan hukuman penjara setinggitingginya dua tahun".

Seperti yang dipantau oleh Relawan TIK Jember. Di Kabupaten Jember, sudah ada 8 kejadian tentang berita palsu atau hoax. Tentu masih banyak lagi yang belum terpantau oleh relawan TIK Jember karena memang kurangnya sumberdaya dari relawan sendiri. Dan juga kurangnya literasi digital kepada masyarakat jember. Kasus Hoax terjadi dan begitu pesat penyebarannya dikarenakan faktor 
masyarakat yang mudah percaya. Sehingga penyebaran informasi mudah tersebar dari mulut ke mulut baik itu tersebar melalui media oline seperti whatsapp dan facebook. Dan salah satu desa yang akan diteliti oleh peneliti adalah Desa Sanenrejo, Kecamatan Tempurejo, Kabupaten Jember.

\subsection{Rumusan Masalah}

Berdasarkan uraian dalam latar yang telah disebutkan diatas, permasalahan yang ingin diketahui dalam penelitian ini dapat dirumuskan sebagaimana berikut :

1. Bagaiamana efektivitas pasal 28 ayat (1) UU ITE tentang penyebaran berita bohong (hoax) di Desa Sanenrejo Kecamatan Tempurejo Kabupaten Jember?

2. Apa hambatan pemerintah desa Sanenrejo Kecamatan Tempurejo Kabupaten Jember untuk mengurangi tindakan penyebaran berita bohong (hoax)?

\section{TINJAUAN PUSTAKA}

\subsection{Tinjauan Tentang Hoax}

\section{a. Definisi Hoax}

Hoax adalah kabar, informasi, berita palsu atau bohong. Sedangkan dalam KBBI disebut dengan hoaks yang artinya berita bohong. Hoax merupakan ekses negatif kebebasan berbicara dan berpendapat di internet. Khususnya media sosial dan blog.
Sedangkan menurut wikipedia, hoax adalah usaha untuk menipu atau mengakali pembaca/ pendengarnya untuk mempercayai sesuatu, padahal sang pencipta berita palsu tersebut tahu bahwa berita tersebut adalah palsu. Hoax bertujuan membuat opini publik, menggiring opini, membentuk persepsi, juga untuk bersenangsenang yang menguji kecerdasan dan kecermatan pengguna internet dan media sosial.

\section{b. Muncul dan Berkembangnya Hoax}

Hoax dibuat seseorang atau kelompok dengan beragam tujuan, mulai dari sekedar main-main, hingga tujuan ekonomi (penipuan), dan politik (propaganda/ pembentukan opini publik) atau agitasi (hasutan). Hoax biasanya muncul ketika sebuah isu mencuat ke permukaan, namun banyak hal yang belum terungkap atau menjadi tanda tanya.

Di Indonesia, hoax marak sejak pemilihan presiden 2014 sebagai dampak gencarnya kampanye di media sosial. Hoax bermunculan guna menjatuhkan citra lawan politik alias kampanye hitam alias kampanye negatif. Menurut Dewan Pers, di Indonesia maraknya hoax juga karena adanya krisis kepercayaan terhadap media mainstream sehingga publik menjatuhkan ke media abal-abal. Menurut Yosep Adi Prasetyo selaku Ketua Dewan Pers hoax merupakakan dampak berubahnya fungsi media sosial dari media pertemanan dan 
berbagi sarana menyampaikan pendapat politik dan mengomentari pendirian orang lain.

\section{c. Ciri-Ciri Berita Hoax}

a. Didistribusikan via email atau media sosial karena efeknya lebih besar

b. Berisi pesan yang membuat cemas, panik para pembacanya

c. Diakhiri dengan himbauan agar si pembaca segera memforwardkan warning tersebut ke forum yang lebih luas. Hoax memanfaatkan iktikad baik si pembaca, sehingga pembaca email ini tanpa meneliti terlebih dahulu kebenaran beritanya, langsung segera menyebarkannya ke forum yang lebih luas. Akibarnya lalu lintas peredaran data di internet makin padat dengan berita yang tidak benar.

d. Biasanya pengirim awal hoax ini tidak diketahui identitasnya.

\subsection{Tinjauan Media Sosial}

\section{a. Konsep Media Sosial}

Media Sosial adalah sebuah media untuk bersosialisasi satu sama lain dan dilakukan secara online yang memungkinkan manusia untuk saling berinteraksi tanpa dibatasi ruang dan waktu.

Menurut Andreas Kaplan dan Michael Haenlein mendefinisikan media sosial sebagai sebuah kelompok aplikasi berbasis internet yang dibangun diatas dasar ideologi dan teknologi Web 2.0, dan memungkinkan penciptaan dan pertukaran user-generated content. Web 2.0 menjadi platform dasar media sosial. Media sosial ada dalam ada dalam berbagai bentuk yang berbeda, termasuk social network, forum internet, weblogs, social blogs, micro blogging, wikis, podcasts, gambar, video, rating, dan bookmark sosial. Menurut Kaplan dan Haenlein ada enam jenis media sosial: proyek kolaborasi (misalnya, wikipedia), blog dan microblogs (misalnya, twitter), komunitas konten (misalnya, youtube), situs jaringan sosial (misalnya facebook, instagram), virtual game (misalnya world of warcraft), dan virtual social (misalnya, second life).

\section{b. Jenis Media Sosial}

Dari berbagai sosial media yang aktif sekarang, ada beberapa sosial media yang mempunyai pengguna aktif sukup besar dan biasa digunakan untuk membagikan banyak berita. Beberapa sosial media tersebut antara lain :

\section{Facebook}

Facebook merupakan salah satu layanan jejaring sosial yang sangat populer di kehidupan masyarakat di dunia saat ini. Seperti jejaring sosial lainnya facebook dapat menghubungkan individu dari berbagai belahan dunia dan sebagai alat komunikasi dan berinteraksi walaupun jaraknya begitu jauh. Facebook berkembang sangat pesat. Hal ini buka tanpa alasan, mengingat penggunaannya 
terbilang mudah serta mempunyai layanan-layanan yang lengkap seperti berbagi foto, vidio, tautan (berita), chatting (berkirim pesan), dll. Layananlayanan tersebut membuat pengguga dimanjakan dan membuat pengguna semakin menikmati facebook)

\section{Instagram}

Instagram merupakan salah satu jejaring sosial populer saat ini. Instagram adalah suatu jejaring sosial yang di dalamnya fokus kepada berbagi foto penggunanya. Nama instagram terdiri dari dua kata yaitu "insta" dan "gram". Insta berasal dari kata instan, yang dapat diartikan dengan kemudahan dalam mengambil dan melihat foto. Gram berasal dari kata telegram, yang dapat diartikan dengan mengirimkan sesuatu(foto) kepada orang lain. Dalam instagram pengguna dapat membagikan foto kepada teman-teman yang terhubung serta kepada pengguna instagran secara umum. Dalam membagikan foto pengguna dapat menuliskan sebuah keterangan untuk menyertai foto tersebut.

\section{Twitter}

Twitter merupakan sebuah situs web yang dimiliki dan dioperasikan oleh Twitter,inc dan merupakan salah satu layanan jejaring sosial dan microblog daring yang memungkinkan para penggunanya untuk mengirim, menerima dan membaca pesan berbasis teks yang jumlah karakternya mencapai 140 karakter, yang dikenal dengan sebutan kicauan (tweet). Twitter adalah salah satu jejaring sosial yang banyak diminati oleh penduduk dunia. Sebagian besar penduduk dunia menganggap bahwa twitter adalah salah satu jejaring sosial yang mudah digunakan dan efisien. Maka dari itu, pengguna Twitter dari tahun ke tahun selalu meningkat drastis

\section{BlackBarry Massenger}

(BBM Merupakan aplikasi pengirim pesan instan yang di sediakan untuk para pengguna perangkat BlackBarry, aplikasi ini mengadopsi kemampuan fictur atau aktifotas yang popular di gunakan di kalangan pengguna perangkat telepon gemgam. Contohmya fictur aplikasi Google Maps atau Yahoo Masangger hingga aktifitas dengan Facebook atau Twetter, semua di dapatkan dengan para pengguna perangkat BlackBarry aplikasi ini merupakan salah satu ke unggulan dari penggunanya selain pelayanan Push Mail. Layanan Masangger ini di buat khusus bagi pemilik BlackBarry dan di rancang khusus untuk berkomunikasi antar penggunanya.

5. Whatsapp Merupakan aplikasi pesan untuk smartphone dengan basic mirip BlackBarry Masangger, Whatsapp Masangger merupakan aplikasi pesan lintas platform yang memungkinkan kita 
bertukar pesan tanpa biaya sms, karena Whatsapp Masangger menggunakan paket data internet yang sama untuk email, brosing website, dan lainya. Aplikasi whatsaap masangger menggunakan koneksi $3 \mathrm{G}$ atau wifi untuk komunikasi data, dengan menggunakan whatsapp, kita dapat melakukan obrolan online, berbagi file, bertukar foto dan yang lainya

Semua pihak yang peduli merasa yakin bahwa jaringan kerja sama sangat menentukan keberhasilan tugas untuk melindungi anak korban kekerasan seksual sekaligus membantu menyelesaikan masalahnya. Adapun Institusi yang terkait dengan masalah kekerasan terhadap anak : Instansi Pemerintah dan Instansi atau Lembaga Non Pemerintah.

\section{PEMBAHASAN}

\subsection{Penerapan Pasal 28 Ayat (1) UU ITE} Tentang Penyebaran Berita Bohong (Hoax) di Desa Sanenrejo

Hoax atau informasi bohong menjadi fenomena di Indonesia yang sengaja disamarkan agar terlihat benar, hal ini tidak luput dari karakteristik masyarakat Indonesia yang banyak menggunakan media sosial. Dengan demikian setiap harinya masyarakat menerima berita maupun informasi dengan cepat melalui perangkat media sosial. Pemerintah sudah seharusnya mulai serius untuk menangani penyebaran berita hoax seperti ini, Pemerintah indonesia membuat peraturan perundangan mengenai penyebaran kabar bohong yang sengaja disebarkan sehingga menimbulkan kerugian bagi pihak yang dijatuhkan.

Hingga saat ini pengguna aktif ponsel di Indonesia telah mencapai 281,9 juta masyarakat berserta SIM cardnya. Dengan demikian, mereka bisa berbagi informasi dengan cepat. Media sosial dan aplikasi pengirim pesat cepat (chat apps) menjadi media favorit (Rudiantara Menteri Komunikasi dan Rudiantara, dikutip dari kompas.com). Sementara Guru besar Ilmu Komunikasi Universitas Padjajaran, Bandung, Deddy Mulyana, menyebut ada faktor utama yang menyebabkan informasi palsu (hoax) mudah tersebarnya di Indonesia. Faktor itu yakni karakter asli masyarakat.

Banyak berita dan Informasi yang di produski secara tidak bertanggung jawab tak terbendung mengalir via internet ke media sosial di komputer maupun smartphone. Akibat terjadinya tingkat kepercayaan yang rendah terhadap wartawan dan media, masyarakat terkadang berasumsi sendiri tentang berita yang didapat dari oknum penyebar hoax padahal berita tersebut belum benar dan belum bisa dipercaya biasa. Menurut Faizal Rahman selaku jurnalis Gerakan Anti Hoax Kaltim 
Pembuat berita hoax biasa dilakukan secara individual yang artinya dibuat oleh akunakun personal, di media sosial sendiri biasa dilakukannya penyebaran berita melalui grup-grup yang ada di media sosial seperti facebook, whatsap, twitter. Banyaknya informasi yang masuk di media sosial dan di group-grup akun personal tanpa disadari Berita palsu mudah di share atau dibagikan. Dan berita palsu ini memberikan dampak negatif kepada para khalayak khususnya kepada para khalayak yang menerima informasi tersebut.

Beberapa contoh kasus diatas mengindikasikan bahwa berita hoax sudah semakin marak terjadi di media sosial maupun isu/gosip yang dibuat oknum yang tidak bertanggung jawab, hal ini banyak membawa pengaruh negatif dalam kehidupan di masyarakat. Hal ini pun tentunya harus menjadi perhatian khusus pemerintah untuk menangani tersebarnya isu-isu hoax. Kini pemerintah dan Jurnalis, juga Polisi memantau media-media online pembuat dan penyebar hoax. Penyebar hoax itu menjalankan pola "hit and run" (melempar isu, tutup lalu pergi) ini benarbenar membuat repot para Pemerintah yang ingin memberantas hoax.

Indonesia yang dinilai tidak terbiasa berbeda pendapat atau berdemokrasi secara sehat. Kondisi itu merupakan salah satu faktor mudahnya masyarakat menelan hoax yang disebarkan secara sengaja. "Sejak dulu orang Indonesia suka berkumpul dan bercerita. Sayangnya, apa yang dibicarakan belum tentu benar. Sebab budaya kolektivisme ini tidak diiringi dengan kemampuan mengolah data," kata Deddy melalui keterangan tertulisnya, Rabu (8/2/2017). Menurut Deddy, kebanyakan masyarakat tidak terbiasa mencatat dan menyimpan data sehingga sering berbicara tanpa data. Di sisi lain, ia menyebut masyarakat lebih senang membahas aspekaspek yang berkaitan dengan kekerasan, sensualitas, drama, intrik dan misteri. "Politik adalah bidang yang memiliki aspek-aspek tersebut. Sehingga hoax sering sekali terjadi pada tema politik. Khususnya saat terjadi perebutan kekuasaan yang menjatuhkan lawan seperti pilpres tahun 2019 saat ini.

Berdasarkan hasil penelitian yang dilakukan Atik Astrini (2017) dalam jurnal Transformasi no.32 tahun 2017 "hoax dan Banalitas Kejahatan" mengemukakan bahwa penyebaran hoax dimedia social dan media online tidaklah terjadi begitu saja tanpa kepentingan yang melatarbelakanginya. Ada kepentingan dibaliknya baik politik kekuasaan, ekonomi (industry dan bisnis hoax), ideologis, sentiment pribadi dan iseng. Selanjutya berdasarkan hasil riset yang dilakukan Mastel (Masyarakat Telematika Indonesia), hasilnya menunjukkan isu politik dan SARA merupakan hal yang paling sering 
diangkat menjadi materi untuk konten hoax. Isu sensitif soal sosial, politik, lalu suku, agama, ras, dan antar golongan, dimanfaatkan para penyebar hoax untuk memengaruhi opini publik, sebanyak 91,8\% responden mengaku paling sering menerima konten hoax tentang sosial politik, seperti pemilihan kepala daerah dan pemerintahan. Tidak beda jauh dengan sosial politik, isu SARA berada di posisi kedua dengan angka 88,6\%. Bentuk konten hoax yang paling banyak diterima responden adalah teks sebanyak 62,1\%, sementara sisanya dalam bentuk gambar sebanyak $37,5 \%$, dan video $0,4 \%$. Sebanyak 92,4 responden menyatakan mendapatkan konten hoax melalui media sosial, media sosial tersebut adalah Facebook, Twitter, Instagram, dan Path. Angka ini cukup jauh jika dibandingkan dengan situs web $(34,9 \%)$, televisi $(8,7 \%)$, media cetak (5\%), email $(3,1 \%)$, dan radio $(1,2 \%)$. Hal ini disebabkan karena masyarakat menyukai hal-hal yang menghebohkandan pada dasarnya sangat berbahaya, karena hal ini bisa menjadi perilaku. Pengguna media sosial bisa memproduksi hoax agar bisa menimbulkan kehebohan.

Undang-undang ITE pasal 28 ayat 2 menyebutkan "dengan sengaja dan tanpa hak menyebarkan informasi yang ditujukan untuk menimbulkan rasa kebencian atau permusuhan individudan atau kelompok masyarakat tertentu berdasasrkan suku, agama, ras dan antargolongan (SARA)". Peran Dinas Komunikasi dan Informasi pada undang-undang ITE yaitu sebagai ahli saksi,memberikan informasi kepada masyarakat tentang penggunaan komputer dan smartphone dalam berhati-hati memposting /share kepada teman dengan kata-kata yang tidak baik, ancaman, pornografi, kebohongan. Undang-undang ITE ini memberikan batasan dimana masyarakat tidak boleh sembarang membuat berita atau informasi, baik berkaitan dengan hoax pembohongan, transaksi yang tidak benar sehingga merugikan bagi semua pihak, itu bisa dikenakan saksi undang-undang ITE pasal 27 dan pasal 28 dan itu berlaku bagi semua masyarakat siapa saja yang membuat berita hoax pada pasal 45 akan dikenakan denda sebesar 1 miliar dan kurungan 6 tahun penjara.

Berita hoax adalah berita bohong yang kebenarannya tidak dapat dipertanggungjawabkan ole siapapun bahkan oleh pembuatnya sendiri. Berikut, alasan

mengapa konten hoax tersebar luas di jejaring sosial:

1. Hanya sebuah humor demi kesenangan belaka. Setiap orang memiliki carasendiri untuk membuat dirinya merasa senang. Dengan kecanggihan teknologi zaman sekarang, orang bisa melakukan hal-hal yang aneh, langka 
dan tidak logis. Namun menimbulkan decak kagum yang lucu dan penuh fantasi.

2. Ini hanyalah usaha untuk mencari sensasi di internet dan media sosial. Biasanya untuk merebut perhatian lebih banyak user, pemilik website dengan sengaja memberikan konten lebay sekedar untuk mencari perhatian publik..

3. Beberapa memang menggunakannya (menyebarkanhoax) demi untuk mendapat lebih banyak uang dengan bekerjasama dengan oknum. (Kasus Saracen)

4. Hanya untuk ikut-ikutan agar terlihat lebih seru. Ini juga merupakan salah satu strategi internet marketing dengan menyuguhkan berita yang lebay maka akan semakin banyak komentar dan like kesana sehingga kelihatan lebih hidup dan lebih ramai.

5. Untuk menyudutkan pihak tertentu (black campaign). Keadaan ini sering terjadi saat sedang berlangsungnya Pilkada/ Pilgub/ Pileg/ Pilpres. Begitulah manusia saat hawa nafsunya tinggi untuk memiliki jabatan alhasil segala cara akan ditempuhnya alias menghalalkan segala cara.

6. Sengaja menimbulkan keresahan. Saat situasi jelek/ rumit mulai tersebar maka muncullah kekuatiran di dalam masyarakat. Beberapa orang memanfaatkan keresahan ini untuk meraup untung yang sebesar-besarnya. Istilahnya adalah "memancing di air keruh" dan "memanfaatkan kesempatan dalam kesempitan".

7. Niatan untuk mengadu domba. Inilah yang sering terjadi pada saat ini yaitu ada oknum yang tidak bertanggungjawab melakukan penyebaran hoax hanya untuk mengadu domba tanpa kepentingan tertentu ataupun menjatuhkan kedua lawan. Dengan contoh politik yang ada saat ini lebih kepada politik adu domba.

Berdasarkan penelitian yang dilakukan Ruri Rosmalinda (2017) penyebab munculnya adalah karena beberapa factor diantaranya :

1. Kemudahan bagi masayarakat dalam memiliki alat komunikasi yang modern dan murah, dalam hal ini adalah penggunaan smartphone sebagai media pencarian informasi

2. Masyarakat mudah terpengaruh oleh isu-isu yang belum jelas tanpa memverifikasi atau mengkonfirmasi kebenaran informasi/berita tersebut, sehingga langsung melakukan tindakan share informasi yang belum jelas kebenarannya.

3. Kurangnya minat membaca, sehingga ada kecenderungan membahas berita tidak berdasarkan data akurat, hanya 
mengandalkan daya ingat atau sumber yang tidak jelas.

\subsection{Hambatan Pemerintah Desa}

Sanenrejo Kecamatan Tempurejo Kabupaten Jember untuk Mengurangi Tindakan Penyebaran Berita Bohong (hoax)

Berdasarkan 15 kuisioner yang peneliti sebarkan, terdapat 12 responden yang menyatakan bahwa pernah ada berita hoax yag tersebar di Desa Sanenrejo, Kecamatan Tempurejo, Kabupaten Jember. Berita hoax yng disebarkan tersebut adalah mengenai virus tanaman sengon, sehingga peduduk menjual tanaman sengonnya sebelum waktunya dijual. Selain itu, terdapat beberapa hambatan untuk mencegah penyebaran berita hoax tersebut. Penegakan hukum mengalami beberapa kendala atau hambatan yang dipengaruhi oleh beberapa faktor-faktor. Antara lain:

a. Substansi hukum yang akan ditegakan;

b. Struktur para penegak hukum; dan

c. Kultur masyarakat.

Pokok penegakan hukum sebenarnya terletak pada faktor-faktor lain yang mungkin mempengaruhinya. Faktor-faktor tersebut mempunyai arti yang netral, sehingga dampak positif atau negatifnya terletak pada isi faktor-faktor tersebut. Faktor-faktor tersebut adalah, sebagai berikut:
1. Faktor hukumnya sendiri, dalam hal ini dibatasi pada undang-undang saja;

2. Faktor penegak hukum, yakni pihakpihak yang membentuk maupun menerapkan hukum;

3. Faktor sarana atau fasilitas yang mendukung penegakan hukum;

4. Faktor masyarakat, yakni lingkungan dimana hukum tersebut berlaku atau diterapkan;

5. Faktor kebudayaan, yakni sebagai hasil karya, cipta, dan rasa yang didasarkan pada karsa manusia di dalam pergaulan hidup.

Kelima faktor tersebut saling berkaitan dengan eratnya, oleh karena merupakan esensi dari penegakan hukum, juga merupakan tolak ukur daripada efektivitas penegakan hukum. Kelima faktor tersebut akan dibahas lebih lanjut sebagai berikut:

1. Undang-undang

Undang-undang dalam arti material adalah peraturan tertulis yang berlaku umum dan dibuat oleh Penguasa Pusat maupun Daerah yang sah. Mengenai berlakunya undang-undang tersebut, terdapat beberapa asas yang tujuannya adalah agar undang-undang tersebut mempunyai dampak yang positif. Asasasas tersebut antara lain.

1. Undang-undang tidak berlaku surut.

2. Undang-undang yng dibuat oleh penguasa yang lebih tinggi; 
Hukum pidana sendiri adalah bagian daripada keseluruhan hukum yang berlaku di suatu negara, yang mengadakan dasardasar dan aturan-aturan untuk:

1. Menentukan perbuatan-perbuatan mana yang tidak boleh dilakukan, yang dilarang, dengan disertai ancaman atau sangsi yang berupa pidana tertentu bagi bagi siapa yang melarang larangan tersebut;

2. Menentukan kapan dan dalam hal-hal apa kepada mereka yang telah melanggar larangan-larangan itu dapat dikenakan atau dijatuhi pidana sebagai mana yang diancamkan;

3. Menentukan dengan cara bagaimana pengenaan pidana itu dapat dilaksanakan apabila ada orang yang disangka telah melanggar larangan tersebut.

Fungsi utama hukum pidana adalah kejahatan sebagai suatu gejala masyarakat. Tujuan hukum pidana ada dua macam, antara lain:

1.Untuk menakut-nakuti setiap orang agar mereka tidak melakukan perbuatan pidana (fungsi preventif); dan

2. Untuk mendidik orang yang telah melakukan perbuatan yang tergolong perbuatan pidana agar mereka menjadi orang yang baik dan dapat diterima kembali dalam masyarakat (fungsi reprensif).
1. Penegak Hukum

Penegak hukum merupakan golongan panutan dalam masyarakat, yang hendaknya mempunyai kemampuan-kemampuan tertentu sesuai dengan aspirasi masyarakat. Mereka harus dapat berkomunikasi dan mendapat pengertian dari golongan sasaran, disamping mampu menjalankan atau membawakan peranan yang dapat diterima oleh mereka. Ada beberapa halangan yang mungkin dijumpai pada penerapan peranan yang seharusnya dari golongan sasaran atau penegak hukum, Halangan-halangan tersebut, adalah:

1. Keterbatasan kemampuan untuk menempatkan diri dalam peranan pihak lain dengan siapa dia berinteraksi;

2. Tingkat aspirasi yang relatif belum tinggi;

3. Kegairahan yang sangat terbatas untuk memikirkan masa depan, sehingga sulit sekali untuk membuat proyeksi;

4. Belum ada kemampuan untuk menunda pemuasan suatu kebutuhan tertentu, terutama kebutuhan material;

5. Kurangnya daya inovatif yang sebenarnya merupakan pasangan konservatisme. Halangan-halangan tersebut dapat diatasi dengan 
membiasakan diri dengan sikapsikap, sebagai berikut:

a. Sikap yang terbuka terhadap pengalaman maupun penemuan baru;

b. Senantiasa siap untuk menerima perubahan setelah menilai kekurangan yang ada pada saat itu;

c. Peka terhadap masalah-masalah yang terjadi di sekitarnya;

d. Senantiasa mempunyai informasi yang selengkap mungkin mengenai pendiriannya;

e. Orientasi ke masa kini dan masa depan yang sebenarnya merupakan suatu urutan;

f. Menyadari akan potensi yang ada dalam dirinya;

g. Berpegang pada suatu perencanaan dan tidak pasrah pada nasib;

h. Percaya pada kemampuan ilmu pengetahuan dan teknologi di dalam meningkatkan kesejahteraan umat manusia;

i. Menyadari dan menghormati hak, kewajiban, maupun kehormatan diri sendiri dan pihak lain;

j. Berpegang teguh pada keputusankeputusan yang diambil atas dasar penalaran dan perhitingan yang mantap. Faktor ini meliputi pihakpihak yang membentuk maupun menerapkan hukum atau law enforcement, adalah aparatur penegak hukum yang mampu memberikan kepastian, keadilan, dan kemanfaatan hukum secara proporsional. Aparatur penegak hukum menyangkut pengertian mengenai institusi penegak hukum dan aparat (orangnya) penegak hukum, sedangkan aparat penegak hukum dalam arti sempit dimulai dari kepolisian, kejaksaan, kehakiman, penasehat hukum dan petugas sipir lembaga pemasyarakatan. Aparat dan aparatur diberikan kewenangan dalam melaksanakan tugasnya masing-masing, yang meliputi kegiatan penerimaan laporan, penyelidikan, penyidikan, penuntutan, penbuktian, penjatuhan vonis dan pemberian sanksi, serta upaya pembinaan kembali terpidana.

Sistem peradilan pidana harus merupakan kesatuan terpadu dari usaha-usaha untuk menangulangi kejahatan yang sesungguhnya terjadi dalam masyarakat. Sistem peradilan pidana akan dinilai berdasarkan jumlah kejahatan yang sampai alat penegak hukum. Secara sosiologis, setiap aparat penegak hukum tersebut mempunyai kedudukan (status) dan 
peranan (role). Kedudukan (sosial) merupakan posisi tertentu di dalam struktur kemasyarakatan. Kedudukan tersebut merupakan peranan atau role, oleh karena itu seseorang yang mempunyai kedudukan tertentu, lazimnya mempunyai peranan. Suatu hak merupakan wewenang untuk berbuat dan tidak berbuat, sedangkan kewajiban adalah beban atau tugas. Suatu peranan tertentu dapat di jabarkan dalam unsur- unsur sebagai berikut:

1. Peranan yang ideal / ideal role;

2. Peranan yang seharusnya / expected role;

3. Peranan yang dianggap oleh diri sendiri / perceived role; dan

4. Peranan yang sebenarnya dilakukan / actual role.

Aturan para aparat dan aparatur penegak hukum dijabarkan sebagai berikut:

1. Kepolisian, kekuasaan polisi/polri adalah merupakan sebagai perwujudan istilah yang mengambarkan penjelmaan tugas, status, organisasi,wewenang dan tanggung jawab polisi. Secara umum kedudukan, fungsi dan tugas kepolisian diatur dalam UndangUndang Nomor 2 Tahun 2002 tentang Kepolisian RI;

2. Kejaksaan, secara umum kedudukan, fungsi dan tugas kepolisian diatur dalam Undang-Undang Nomor 16

Tahun 2004 tentang Kejaksaan RI;

3. Kehakiman, Secara umum kedudukan, fungsi dan tugas kepolisian diatur dalam UndangUndang Nomor 4 Tahun 2004 tentang Kekuasaan Kehakiman;

4. Lembaga Permasyarakatan, Secara umum kedudukan, fungsi dan tugas kepolisian diatur dalam UndangUndang Nomor 19 Tahun 2005 tentang Permasyarakatan.

Ada tiga elemen penting yang mempengaruhi mekanisme bekerjanya aparat dan aparatur penegak hukum, antara lain:

1. Institusi penegak hukum beserta berbagai perangkat sarana dan prasarana pendukung dan mekanisme kerja kelembagaannya;

2. Budaya kerja yang terkait dengan aparatnya, termasuk mengenai kesejahteraan aparatnya; dan

3. Perangkat peraturan yang mendukung baik kinerja kelembagaanya maupun yang mengatur materi hukum yang dijadikan standar kerja, baik hukum materilnya maupun hukum acaranya.

2. Faktor Sarana atau Fasilitas

Fasilitas pendukung secara sederhana dapat dirumuskan sebagai sarana untuk mencapai tujuan. Ruang lingkupnya terutama adalah sarana fisik yang berfungsi sebagai faktor pendukung. 
Tanpa adanya sarana atau fasilitas tertentu, maka tidak mungkin penegakan hukum akan berjalan dengan lancar. Sarana atau fasilitas tersebut antara lain, mencakup tenaga manusia yang berpendidikan dan terampil, organisasi yang baik, peralatan yang memadai, keuangan yang cukup, dan seterusnya. Sarana atau fasilitas mempunyai peran yang sangat penting dalam penegakan hukum. Tanpa adanya sarana atau fasilitas tersebut, tidak akan mungkin penegak hukum menyerasikan peranan yang seharusnya dengan peranan yang aktual. Khususnya untuk sarana atau fasilitas tesebut, sebaiknya dianut jalan pikiran, sebagai berikut:

1. Yang tidak ada-diadakan yang baru betul;

2. Yang rusak atau salah-diperbaiki atau dibetulkan;

3. Yang kurang-ditambah;

4. Yang macet-dilancarkan;

4. Yang mundur atau merosot-dimajukan atau ditingkatkan. Faktor ketiga yaitu faktor sarana atau fasilitas yang membantu penegakan hukum, menurut Soerjono Soekanto sendiri menyatakan bahwa tidak mungkin penegakan hukum akan berlangsung dengan lancar tanpa adanya sarana atau fasilitas yang memadai. Akan tetapi hal itu bukanlah segala-galanya kalau aparatnya sendiri masih buruk, karena sebaik apapun sarana atau fasilitas yang membantu penegakkan hukum tanpa adanya aparat penegak hukum yang baik hal itu hanya akan terasa sia-sia.

5. Faktor Masyarakat Penegakan hukum berasal dari masyarakat, dan bertujuan untuk mencapai kedamaian dalam masyarakat. Dipandang dari sudut tertentu, maka masyarakat dapat mempengaruhi penegakan hukum tersebut. Masyarakat Indonesia mempunyai kecendrungan yang besar untuk mengartikan hukum dan bahkan mengidentifikasikannya dengan petugas (dalam hal ini penegak hukum sebagai pribadi). Akibatnya adalah, bahwa baik buruknya hukum senantiasa dikaitkan dengan pola prilaku penegak hukum tersebut. Masyarakat Indonesia mempunyai pendapat mengenai hukum sangat berfareasi antara lain:

1. Hukum diartikan sebagai ilmu pengetahuan;

2. Hukum diartikan sebagai disiplin, yakni sistem ajaran tentang kenyataan;

3. Hukum diartikan sebagai norma atau kaidah, yakni patokan perilaku pantas yang diharapkan

4. Hukum diartikan sebagai tata hukum (yakni hukum positif tertulis);

5. Hukum diartikan sebagai petugas atau pejabat; 
6. Hukum diartikan sebagai keputusan pejabat atau penguasa;

7. Hukum diartikan sebagai proses pemerintahan;

8. Hukum diartikan sebagai perilaku teratur dan unik;

9. Hukum diartikan sebagai jalinan nilai;

10. Hukum diartikan sebagai seni. Salah satu akibatnya adalah bahwa baik buruknya hukum senantiasa dikaitkan dengan pola perilaku penegak hukum itu sendiri yang merupakan pendapatnya sebagai cerminan dari hukum sebagai struktur dan proses. Keadaan tersebut juga dapat memberikan pengaruh baik, yakni bahwa penegak hukum akan merasa bahwa perilakunya senantiasa mendapat perhatian dari masyarakat. Permasalahan lain yang timbul sebagai akibat anggapan masyarakat adalah mengenai penerapan undang-undang yang ada / berlaku.

\section{Faktor Kebudayaan}

Kebudayaan (sistem) hukum pada dasarnya mencakup nilai-nilai yang mendasari hukum yang berlaku, nilainilai yang merupakan konsepsi abstrak mengenai apa yang dianggap baik dan apa yang dianggap buruk. Pasangan nilai yang berperan dalam hukum, adalah sebagai berikut :
1. Nilai ketertiban dan nilai ketentraman;

2. Nilai jasmani/kebendaan dan nilai rohani/keakhlakan;

3. Nilai kelanggengan/konservatisme dan nilai kebaruan/inovatisme.

Di Indonesia masih berlaku hukum adat, hukum adat adalah merupakan hukum kebiasaan yang berlaku dalam masyarakat. Faktor kebudayaan sebenarnya bersatu padu dengan faktor masyarakat sengaja dibedakan, karena didalam pembahasannya diketengahkan masalah sistem nilai-nilai yang menjadi inti dari kebudayaan spiritual atau non material. Hal ini dibedakan sebab menurut Lawrence M. Friedman yang dikutip Soerdjono Soekamto, bahwa sebagai suatu sistem (atau subsistem dari sistem kemasyarakatan), maka hukum menyangkup, struktur, subtansi dan kebudayaan. Struktur menyangkut wadah atau bentuk dari sistem tersebut yang umpamanya, menyangkup tatanan lembagalembaga hukum formal, hukum antara lembagalembaga tersebut, hak-hak dan kewajiban-kewajibanya, dan seterusnya. Kebudayaan (sistem) hukum pada dasarnya mencangkup nilai-nilai yang mendasari hukum yang berlaku, nilai-nilai yang merupakan konsepsi-konsepsi abstrak mengenai apa yang dianggap baik dan apa yang dianggap buruk. Nilai-nilai tersebut, lazimnya merupakan pasangan nilai-nilai yang mencerminkan dua keadaan estrim 
yang harus diserasikan. Pasangan nilai yang berperan dalam hukum menurut Soerdjono Soekamto adalah sebagai berikut:

1. Nilai ketertiban dan nilai ketenteraman;

2. Nilai jasmaniah/kebendaan dan nilai rohaniah/keakhlakan;

3. Nilai kelanggengan/konservatisme dan nilai kebaruan/inovatisme. Dengan adanya keserasian nilai dengan kebudayaan masyarakat setempat diharapkan terjalin hubungan timbal balik antara hukum adap dan hukum positif di Indonesia, dengan demikian ketentuan dalam pasal-pasal hukum tertulis dapat mencerminkan nilai-nilai yang menjadi dasar dari hukum adat supaya hukum perundang-undangan tersebut dapat berlaku secara efektif

\section{KESIMPULAN}

Berdasarkan hasil penelitian yang dilakukan dapat diperoleh kesimpulan sebagai berikut :

1. Peristiwa penyebaran berita hoax yang sedang marak terjadi di Indonesia menyebabkan keresahan di masyarakat. Hal ini dapat di sikapi oleh para pengguna media sosial agar menjadi netter yang cerdas dan lebih selektif serta berhati-hati akan segala berita atau pun informasi yang tersebar. Diharapkan pula untuk tidak langsung percaya dari berita atau informasi yang diterima. Cari tahu darimana sumber berita tersebut dan menggali informasi lebih jauh dari berita atau informasi yang didapat. Jangan mudah terprovokasi dengan menyebarluaskan kembali berita atau informasi yang belum jelas benar atau tidaknya. Jadilah pengguna media sosial serta masyarakat Indonesia yang cerdas. Pemerintah diharapkan lebih cepat lagi merespon hoax yang beredar dimasyarakat sehingga dapat meminimalisasi kegaduhan atau keresahan yang terjadi dimasyrakat dan Pemerintah harus lebih giat lagi mensosialisasikan UU ITE agar masyarakat lebih paham lagi cara menggunakan media sosial dan internet dengan cerdas dan bijaksana dan kiraya media sosail dan internet digunakan untuk kebaikan hidup dan membaikkan kehidupan. Dan masih diperlukakan penelitian yang lebih lanjut mengenai penelitian ini.

2. Faktor yang menjadi penghambat dalam penanggulangan berita bohong (hoax), antara lain Faktor aparat penegak hukum, yaitu secara kuantitas masih terbatasnya jumlah penyidik dan secara kualitas sumber daya manusia yang masih belum menguasai tentang ITE, Faktor sarana dan prasarana, Faktor masyarakat, yaitu rendahnya pendidikan dan pemahaman masyarakat terhadap 
informasi, sehingga hoax atau berita bohong gampang tersebar.

\section{DAFTAR PUSTAKA}

\section{BUKU}

Andi Hamzah 1991, Asas-Asas Hukum Pidana, Jakarta: Rineka Cipta.

Burhan Bungi, 2003, Pornomedia: Konstruksi Sosial Telematika dan Perayaan Seks di Media Massa, Jakarta : Prenada Media

Danrivanto Budhijanto, 2010, Hukum Telekomunikasi, Penyiaran dan Tekhnologi Informasi; regulasi dan Konvergensi, Bandung: Refika Aditama

Mahrus Ali, 2011, Dasar-Dasar Hukum Pidana, Jakarta: Sinar Grafika, Jakarta.

Siswanto Sunarso, 2009, Hukum Informasi dan Transaksi Elektronik (Studi Kasus; Prita Mulyasari), Jakarta,Rineka cipta

Widodo, Hukum Pidana di Bidang Teknologi Informasi Cybercrime Law: Telaah Teoritik dan Bedah Kasus (Yogyakarta: Aswaja Pressindo, 2013). 


\section{Undang-Undang}

Undang-Undang Nomor 1 Tahun 1946 Tentang Peraturan Kitab Undang-Undang Hukum Pidana

Undang-Undang Nomor 8 Tahun 1981 Tentang Hukum Acara Pidana

Undang-Undang R.I Nomor 19 Tahun 2016 perubahan atas UndangUndang Nomor 11 tahun 2008 tentang Informasi dan Transaksi Elektronik

\section{Lain-lain}

Gusti Ngurah Aditya Lesmana, Tesis (Program Magister Manajemen, Fakultas Ekonomi, Universitas Indonesia)

KBBI Daring, Hoaks, https://kbbi.kemdikbud.go.id, diakses tanggal 3 April 2019.

Petrus Reinhard Golose, Perkembangan Cybercrime dan Upaya Penanganannya di Indonesia Oleh Polri, Makalah pada Seminar Nasional tentang "Penanganan Masalah Cybercrime di Indonesia dan Pengembangan Kebijakan Nasional yang Menyeluruh Terpadu”, diselenggarakan oleh
Deplu, BI, dan Depkominfo, Jakarta, 10 Agustus 2006.

Ricky Nurdiana, "Mengenal Social Media" http://www.unpas.ac.id, diakses pada 23 Maret 2019 


\section{BIODATA SINGKAT PENULIS}

Firda Laily Mufid, adalah Dosen pada Fakultas Hukum Universitas Islam Jember. Menyelesaikan pendidikan Sarjana pada Fakultas Hukum Universitas Jember dan Magister Ilmu Hukum Fakultas Hukum Universitas Jember.

Tioma R. Hariandja, adalah Dosen Tetap pada Fakultas Hukum Universitas Islam Jember. Menyelesaikan pendidikan Sarjana pada Fakultas Hukum Universitas Airlangga dan Magister Ilmu Hukum Fakultas Hukum Airlangga. 